\title{
ANALYSES OF THE CAUSES OF COMMON RAIL PIEZOELECTRIC AND ELECTROMAGNETIC INJECTORS' PREMATURE DESTRUCTION IN SELF-IGNITION ENGINES
}

In self-ignition engines with Common Rail direct fuel injection, premature destruction of injectors has been observed. New elements are also touched by the problem. In order to solve it, a group of international experts in the area have gathered. Destroyed piezoelectric and electromagnetic injectors' elements of BOSCH, DELPHI, DENSO, have been examined. Mechanical damages influencing electronic diagnostic signal have been presented. Some system solutions possible to perform as far as diagnostic prevention is concerned have been described. Some useful electronic diagnostic methods of fuel system, signal analysers: RMOG and ERDIA PRO, have been presented.

Keywords: Diagnostics of piezoelectric and electromagnetic injectors CR, acoustic emission signature, electronic analysers: RMOG, EDIA PRO.

\section{Introduction}

Direct fuel-injection systems with Common Rail (CR) possess electromagnetic or piezoelectric injectors started with the use of electric signal from the engine controller (EDC_C_).The controller controls the fuel flow through leakage channel and steering dose while direct fuel injection is the result of the fuel pressure difference between high pressure chamber and steering one. In some leakage-free cases of piezoelectric injectors the steering closes the injector with the use of electric signal. Disappearance of the signal opens injector's valve. Mobile elements of injectors are greased with the fuel, the one that is injected to the combustion chamber, not the engine oil. As a result, durability of the injector depends on the quality and clarity of the fuel.

\section{Examination of chosen elements of the fuel system}

Service procedures clearly describe methods used to control Common Rail injectors of both kinds: the piezoelectric as well as electromagnetic ones. The most basic one is the control of the leakage channel and steering dose $[1,2,3,4]$ with the use of specific measurement vessels. This method is possible to perform in some technical cases, e.g. leakage free injectors. This method cannot be used in many cases although it is the most common method used in car services. What is more, it needs the interference of the back flow of the fuel system into the low pressure side. Such a control, in many cases does not give the expected results because it is not possible to control the single fuel injection doses. It happens that in spite of getting the positive test results, the injec- tor will not work properly in the engine. When such a situation occurs, there is a need to set the injector in a special control place, e.g. EPS200A or special assay table. It is possible to run tests there such as measurement of the quality of the injection dose as well as leakages for 1000 fuel injections in correct control pressures of rail and correct injection times e.g. DS2 (Fig. 1), CRU.2, EPS200A (Fig. 2), STPiW - 3 (Fig. 3), EPS708 and EPS815.

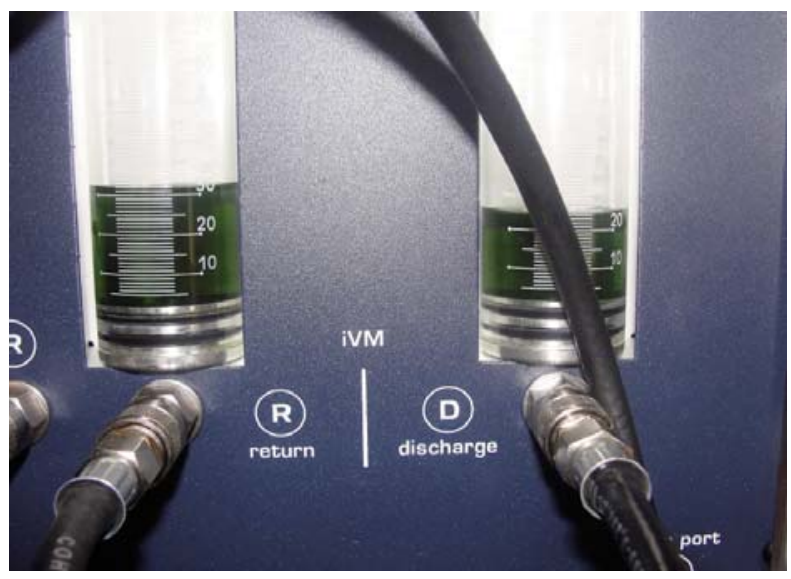

Fig. 1. Examination of the injector with the use of Common Rail injectors diagnostic test stand DS2 by Magneti Marelli

To conclude, in order to correctly check the starting condition of each injector it is needed to control correctness of injec-

\footnotetext{
* Slawomir Olszowski ${ }^{1}$, Jozef Buday ${ }^{1}$, Jozef Kuchta ${ }^{2}$, Jan Michalik ${ }^{2}$

${ }^{1}$ Faculty of Transport and Electrical Engineering, Kazimierz Pulaski University of Technology and Humanities in Radom, Poland,

E-mail: s.olszowski@ekspertyzy-szkolenia.pl

${ }^{2}$ EVPU, Elektrotechnicky vyskumny a projektovy ustav, Nova Dubnica, Slovakia
} 


\begin{tabular}{|c|c|c|c|}
\hline \multicolumn{4}{|l|}{$\begin{array}{l}\text { Dawka powrotna. } \\
\text { (czas stabilizacii } 40 \text { s) }\end{array}$} \\
\hline Czynnosc $2 z 4$ & & Wartosci pomiarove & \\
\hline Nazwa pomiaru & $\mathrm{ML}$ & 150.1 MPa & $3911^{\circ} \mathrm{C}$ \\
\hline Okres zalączania & 900 us & & $34 \mathrm{~s}$ \\
\hline Cisnienie & $160.0 \mathrm{MPa}$ & un & 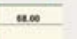 \\
\hline Dawka wtrysku & $58.9 \pm 5.5 \mathrm{~mm}^{3} / \mathrm{H}$ & a. & \\
\hline Dawka powrotna & $43.0 \pm 25.0 \mathrm{~mm}^{2} / \mathrm{H}$ & & \\
\hline Czas pomiaru & $90 \mathrm{~s}$ & & \\
\hline & & श्का & $\mathrm{me}$ \\
\hline & & 25.82 & 3470 \\
\hline$-5=$ & & $=$ & 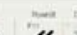 \\
\hline 1 & t & $\square$ & « \\
\hline
\end{tabular}

Fig. 2. Examination of the injector with the use of Common Rail injectors diagnostic test stand EPS 200A by BOSCH

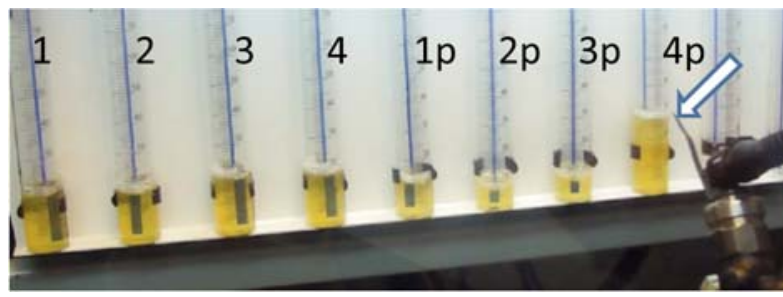

Fig. 3. Measurement of injection dose and volume of the fuel coming through the leakage channel as well as steering dose on the assay table; on the left 1, 2, 3, 4-measurement graduation cylinder of injection dose, $1 p, 2 p, 3 p, 4 p$ - measurement graduation cylinder of leakage channel and steering dose

tion dose (quantitative comparison) for separate cylinders $[5,6]$ or run the tests of injectors with the use of functions available in the service.

\subsection{Laboratory examination of damaged injectors}

When the examination described in point 2 was finished, it was needed to check which elements of injectors are commonly damaged. To achieve this, chosen injectors, their separate parts, have been evaluated again.

\subsubsection{Slide examination of injectors' elements}

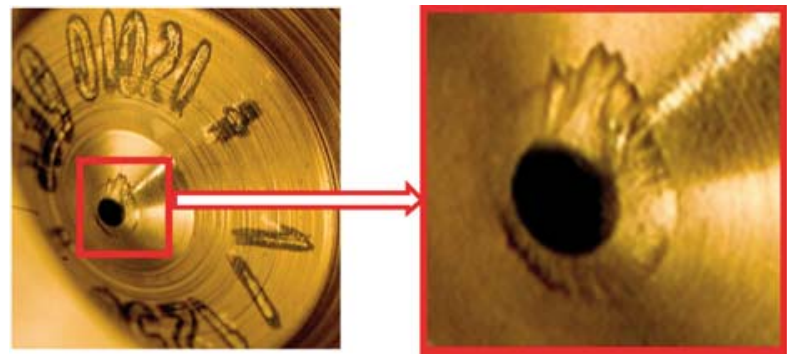

Fig. 4. Damaged steering valve socket in a new injector after the work with the constant contaminants in the fuel

Figs. 4 and 5 present some types of exploitation steering valve socket damages. It is possible to observe damages caused by erosion. They are the results of soft pollution and hard closure of steering valve. The small leakage caused fuel flow under the high pressure from the steering chamber which leads to the permanent damage of the injector.

As it has been proved, injectors of engines with the Common Rail injector system are prematurely damaged even in totally new drive units. Every type of presented damage (Figs. 6, 7, 8) needs
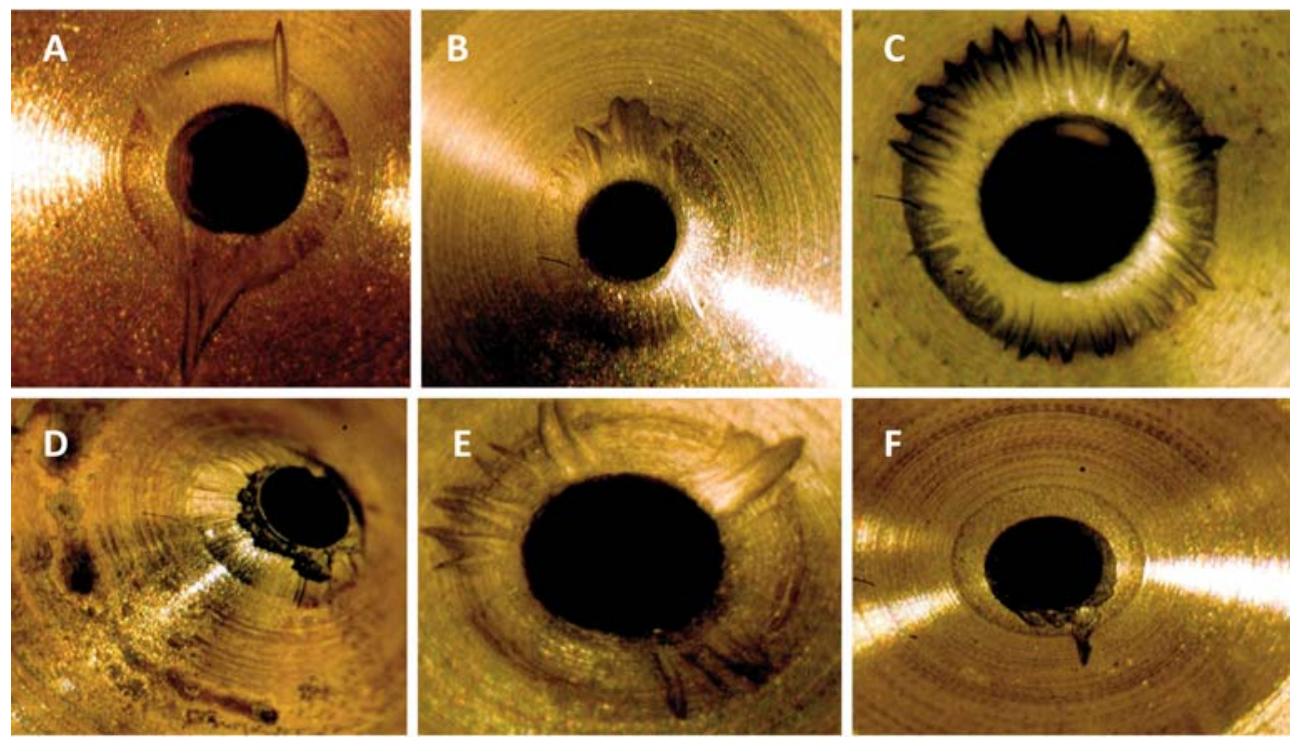

Fig. 5. Examples of damages of steering valve socket while exploitation 

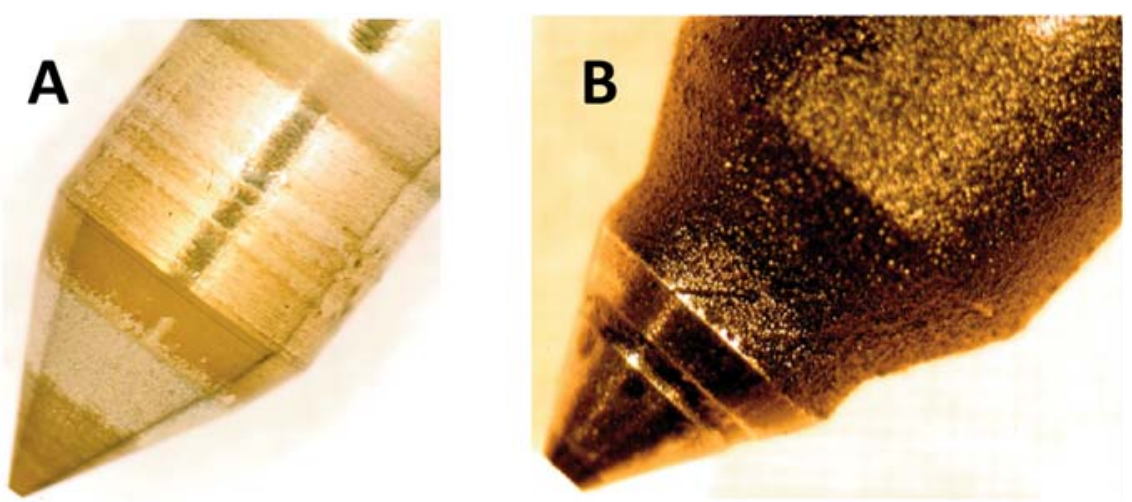

Fig. 6. Examples of damages of atomizer needle. A- lack of lubrication in atomizer frame(oil thinned with petrol), B-engine exploitation with the use of vegetable oil bought in a shop
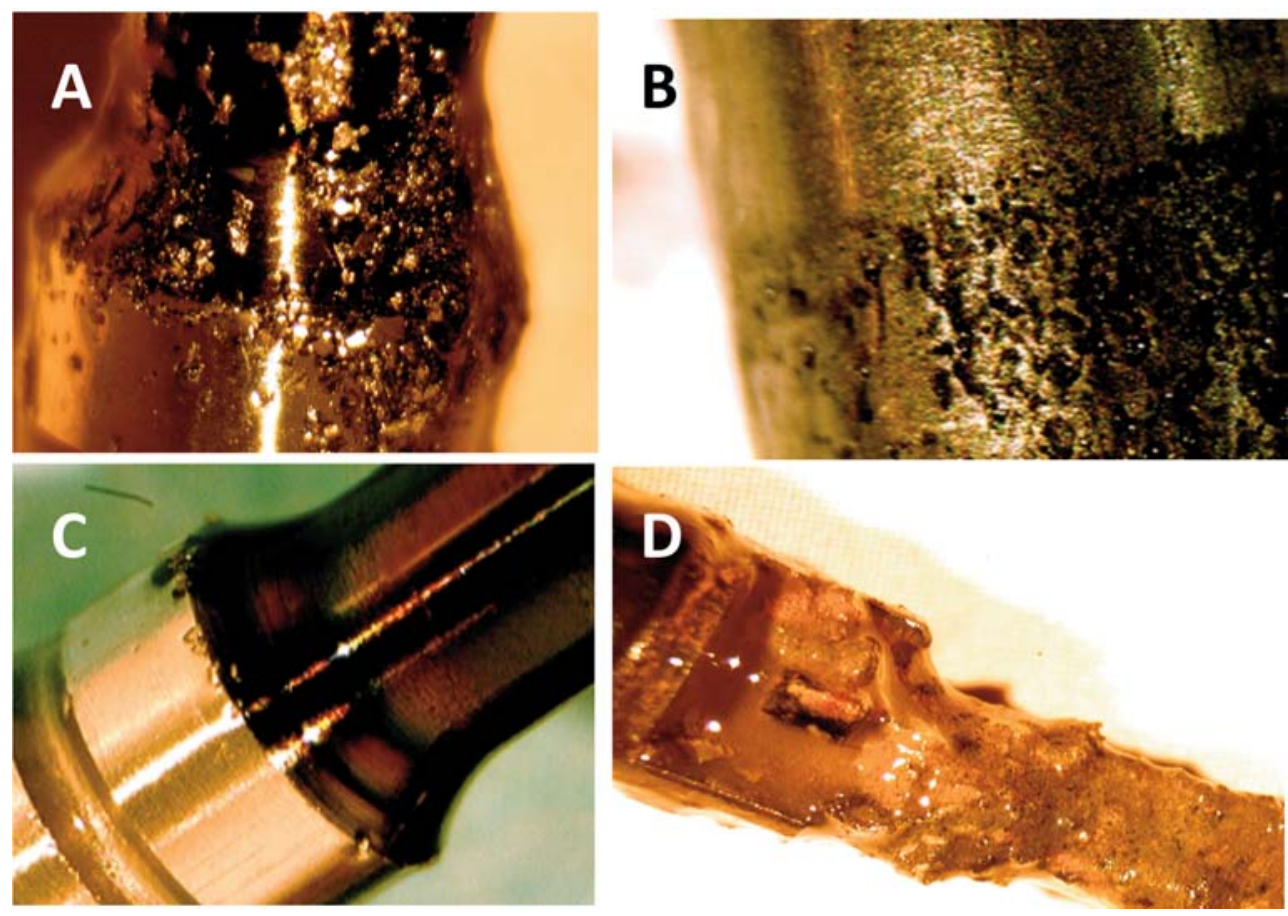

Fig. 7. Other damages of the injectors elements, A-filings in the fuel, B-corrosion of elements, C-beginning of the perspective costs, D-silt in the fuel

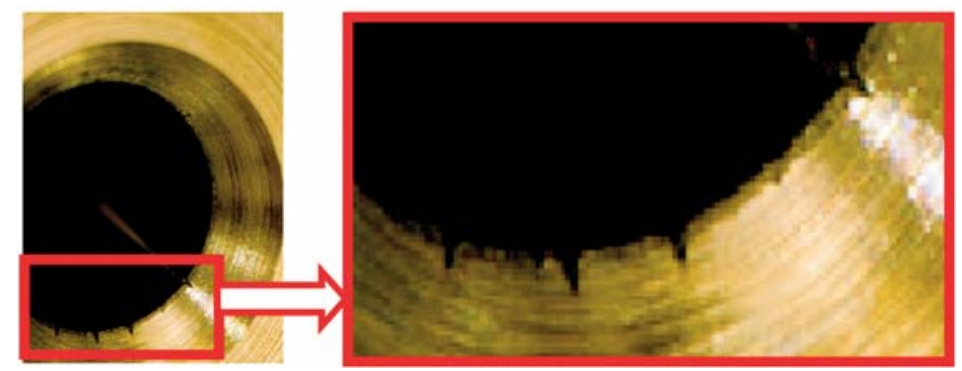

Fig. 8. The example of the injectors leakiness in steering valve socket 
to be treated separately and individually. However, on the basis of the researches, it is possible to point out some general hypotheses of damages' causes. Thanks to it, it seems possible to avoid such problems in the future and solve them fast.

Not only used but also new injectors get damaged.

1. With the use of statistic results of damages presented in the article [1] as well as the results of present injector components it seems possible to state that the most common reason of damages are:

A. Incorrect kind of fuel

B. Polluted fuel

- bad quality fuel filters

- filings from fuel system elements, especially from the high pressure pumps

- water in the fuel

- bad quality fuel.

2. Qualifications of staff in service section.

As it is observed, it is not enough to exchange the damaged element. With the technical development, it is needed to examine the cause of damage. As it has been presented in the research, it is not possible to do the correct diagnoses of the piezoelectric and electromagnetic CR injectors damages' causes without microscopic research.

\section{Final conclusion}

Technology development as far as vehicles are concerned, becomes a real problem for their users because of innovative, advanced systems as well as the level of qualification of the staff of service sector [7]. Innovative technologies used for production of Common Rail injectors, are step forward in range of the accuracy of manufacturing in comparison to the quality of the fuel commonly used on the market.

Bearing in mind the fact that before, it was needed to exchange the fuel filter in self-ignition engine after 30 thousand $\mathrm{km}$. Nowadays it is 60 thousand $\mathrm{km}$, so it seems to be clear that gathering greater amount of money from the sale of more expensive components of injection system was a priority for the producers rather than solving or preventing the problem.

The research team after detailed analyses of the results concluded that the every year examination of the vehicle in the Car Control Station with usage of EDIA Pro and RMOG can be a good solution to prevent the environmental pollution due to the faulty working CR injectors.

It is not possible for a driver to observe the faulty work of the engine in the first phase as HP pump is enough to cover a greater need for fuel, which is a result of the GZS leakiness.

A correct diagnosis can be done by checking the pressure fall in the fuel container with the use of EDIA PRO [8] and with the use of the innovative method RMOG. These methods are additional. The first one, makes it possible to precisely analyze the parameters of fuel system parameters, the second one analyzes spectrum results. This spectrum is a combination of time and frequency of the acoustic emission signal of working injector $[6,9,10]$. However, it is a new innovative method unknown in the world yet.

\section{References}

[1] OLSZOWSKI, S., MARCZAK, M.: Diagnostics of New Generation Diesel Engines. Diagnostyka No. 4(48), 2008, Polskie Towarzystwo Diagnostyki Technicznej, pp. 83-88.

[2] OLSZOWSKI, S.: Innovative Method of Diagnostics of Common Rail Injectors. Czasopismo Logistyka, No. 2, Poznan, 2008.

[3] DOBRUCKY, B., SPANIK, P., SUL, R.: Improvement of Power Electronic Structure Characteristics Using Sic Technology Overview. Communications - Scientific Letters of the University of Zilina, No. 1, 2006

[4] JURISICA, L.: Mechatronics Systems. Communications - Scientific Letters of the University of Zilina, No. 1, 2007

[5] OLSZOWSKI, S.: The Methods of Diagnosis of the Innovatory Management Systems in Cars. IX Inter. conference Transport Systems Telematics. Politechnika Slaska. Katowice-Ustron, November, 2009.

[6] OLSZOWSKI, S.: Common Rail System in Transport Facilities - Current and Future Problems. Czasopismo Drogi, No. 4, pp. 97-103, 2009.

[7] KALLAY. F., PENIAK, P.: The Communication in Mechatronic Systems. Communications - Scientific Letters of the University of Zilina, No. 1, 2007.

[8] OLSZOWSKI, S., OLSZOWSKI, T: Non-invasive Method of Diagnostics Common Rail System Condition. Transcomp - Intern. Conference Computer Systems Aided Science, Industry and Transport, 2012

[9] OLSZOWSKI, S., CHOJNACKI, T.: Diagnostics of Unconventional Defects in the Systems of Cleaning Exhaust Fumes. Transcomp - Intern. Conference Computer Systems Aided Science, Industry and Transport, 2009

[10] OLSZOWSKI, S.: Ecological and Functional Aspect of Technical Exploitation of New Generation Common Rail Systems. Computer systems aided science and engineering work in transport, mechanics and electrical engineering. Monograph. Kazimierz Pulaski Technical University of Radom: Faculty of Transport, pp. 459-465, 2008. 